\title{
INTERACTION BETWEEN THE TRANSPORT NETWORK AND THE TERRITORY OF ALGIERS (COMPLEX SYSTEM): IN SEARCH OF INDICATORS
}

\author{
Nour El Houda BABA SLIMANE ${ }^{\text {a }}$, Tahar BAOUNI ${ }^{\text {a* }}$ \\ ${ }^{a}$ Ecole Polytechnique d'Architecture et d'Urbanisme « EPAU », Laboratoire Ville, Urbanisme et Développement Durable « VUDD », \\ Route de Beaulieu, El-Harrach, BP N 177.16200 Algiers, Algeria, E-mails: n.babaslimane @epau-alger.edu.dz; \\ *t.baouni@epau-alger.edu.dz
}

Received: 31.05.2021 / Accepted: 15.06.2021 / Revised: 16.10.2021 / Available online: 15.12.2021

DOI: 10.2478/jaes-2021-0011

KEY WORDS: Territory, Transport Network, Algiers, Complex System, Indicators.

\begin{abstract}
:
In recent years and within the framework of its project "Algiers the metropolis", Algiers has classified its transport network among its first concerns in order to compete with the other Mediterranean metropolises. However, the complexity of its territory, which is of a particular geological and geomorphological nature, represents a constraint for the proper distribution and management of its transport network. The complexity of its territory and of its transport network, leads us towards the systemic approach for the search of an adequacy between these two complex urban realities in order to find an effective and efficient tool of management and urban planning. The development of a set of indicators of sustainable mobility, as a result of this work, allowed us to find through an epistemological study of the literature on the two complex concepts to select and develop a list of Input and Output Indicators that are related to both territory and transport. Indeed, this list of sustainable mobility indicators will allow, on the one hand, in urban planning, a better match of the transport network to the Algerian territory and, on the other hand, the study of the effectiveness and efficiency of the present and future transport network.
\end{abstract}

\section{INTRODUCTION}

The manufacture of cities, for millennia, reveals a complex and intricate process that was at the origin of their existence. The territory and the transport network are, in fact, the two main elements of this process, as the co-evolution of the two is present and visible in the history of the different cities of the world.

At present, and within all the technical and technological developments, the interaction between transport network and territory remains an important and complex component in urban decisions and strategies.

Therefore, ensuring a good fit between these two components of the manufacturing cities process, in logic of sustainability, is considered important in seeking and developing indicators that ensure this adequacy for better management of the territory and the transport network. Thus, the main question of this problem is: "What are the indicators of sustainable mobility that allow the adequacy between the territorial systems with the transport system?"

Given that the territory and the transport network form a complex process and a strong interdependence (Raimbault, 2018), the study of their interaction calls for a systems approach that involves the interaction between the components of each of these two systems.

The city of Algiers, with its complex and particular territory, appears as an example to study this interaction between its territory and its transport network which is constantly developing. The development of a list of indicators is seen as essential for a better adequacy of these two components and consequently a better management of the city.

The territory, a concept of modern geography and an urban complexity

The territory, this concept of modern geography, has been the subject of several discussions and reflections in recent decades, notably through the numerous definitions given, namely those of Auriac (1984), Raffestin (1986), Brunet (1990), Le Berre (1992), Di Méo (1998), Roland-May (2000), Elissalde (2002), because the concept of territory is the only concept that can explain and represent the complexity that surrounds us, mixing at the same time physical, natural and built environment (Moine, 2006), but before any definition, the territory is considered as a system.

According to Thierry Paquot in 2011, the word 'territory' appeared during the 13th century and its use did not become widespread until the 18th century, which perfectly explains the 
complexity of this concept. It is only a century later that research has focused on this term by trying to define it, as in the case of Daniel Nordman in 1996, who tried to use two definitions of Jean Nicot (1606) and Antoine Furtière (1690) to come up with a summary of the territory. A definition similar to that of space which made this term even more polysemous. Until 1992, Maryvonne Le Berre provides a definition of the territory in geography, for her, the territory "can be defined as a portion of the earth's surface, appropriated by a social group to ensure its reproduction and the satisfaction of its vital needs. It is a spatial entity, the place where the group lives, indissociable from the group". Basically, the word territory, in a geographical reality, is based on a total cultural and geographical fact (Thierry Paquot, 2011).

Given that our research is part of an urban discipline, the definition of territory given by Maryvonne Le Berre in 1992 is the closest to the discipline, as she defines territory as "a portion of the land area delineated and prepared by a community according to its needs, it contains the idea of authority exercising over an area whose boundaries are recognized, and that of use and development by a social group that appropriates it" (Le Berre, 1992), It therefore means that the territory is no longer reduced to a surface of extension of a phenomenon and even less to the notions given by geographers, in relation to the space, on the territory as being a perceived space, a lived space and an adequate space.

The interest in defining this notion is the same for urban planners. André Corboz in 1983 adopted the term "territory" and defined it as a palimpsest and a product of several processes, each with its own temporality and or representation, adding that "the territory is a sort of mille-feuille, each bearing witness to an episode in the long and turbulent history of this "Male/Nature" couple". (Thierry Paquot, 2011).

On the other hand, the technological advances and deployment that aim at the globalisation of the economy in the name of profitability make person seconded from their territory in a trend of self-sustainability. Of which, Alberto Magnaghi in 2018 explains that the territory then becomes a territorial ecosystem and a territory of the common.

Given that the territory is ultimately a complex system, according to Alexandre Moine, "the territory is therefore, before any definition, a system. And yet it is never really defined as such..." (Moine, 2006), and returning to Le Berre's 1992 definition, the latter is composed of three facets (see Table 1).

\begin{tabular}{|l|l|}
\hline $\begin{array}{l}\text { A territorial } \\
\text { entity }\end{array}$ & the identity card where the sense of belonging comes \\
\hline $\begin{array}{l}\text { Physical } \\
\text { materiality }\end{array}$ & $\begin{array}{l}\text { These are the natural properties (topography, } \\
\text { morphology, etc.) and material properties which are } \\
\text { the various developments made by the companies } \\
\text { which have appropriated the territory. }\end{array}$ \\
\hline $\begin{array}{l}\text { A social } \\
\text { organisation }\end{array}$ & $\begin{array}{l}\text { the social group that occupies the territory through its } \\
\text { different degrees of cohesion }\end{array}$ \\
\hline
\end{tabular}

Table 1 . The three aspects of the territory provided by Le Berre in 1992 (Le Berre 1992, adapted by author)
In short, these three aspects of the territory interact and retroact on each other, which gives it this complexity and maintains complex relations, and consequently, the systemic paradigm becomes necessary to apprehend this concept. In the end, the complexity of this system comes down to the components of the links between them and the exchanges it maintains with the surrounding systems.

The territory as a complex system is composed of several subsystems, of which Alexandre Moine identifies three: the spatial sub-system, the actor sub-system and the representations subsystem, all of which are subject to a major feedback loop (Moine, 2006; 2008). The first "spatial" sub-system is represented by the physical and/or natural environment, which is appropriated and developed by the second "actor" sub-system, which is represented by the state, local authorities, companies, groups and individuals (Brunet, 1990). The latter act on the basis of their findings, the knowledge of the territory, their representations of it, and the freedom afforded them by the management system in which they operate (Moine, 2006). Consequently, actors create the physiognomy of tomorrow's geographical space by inheriting both the physical environment and the developments produced by previous societies (Saint Amant, 2011).

In the end, the opening of this system allows it to maintain relations with surrounding systems that can also be complex, namely the transport system which constitutes "the solution, constantly renewed, to the problem of a human society living on a differentiated surface" (Chesnais, 1980).

On the same basis as the territory, transportation also remains a complex and still unclear system, as "the transportation system refers to several elements that make its definition relatively complex" (Chapelon, 1998).

\section{Transport, a fairly complex definition}

Transport is an activity that allows the transport and or carrying of elements or people in a given space according to the classic definitions of the Petit Larousse dictionaries. Based on this definition, several other authors, including Michel Didier in 2007, have defined it as an intermediate consumption service that constitutes an auxiliary to professional activity, leisure or production.

In contrast, the definition of transport has always been linked to the concept of space, territory and city. This concept of transport is considered by Pumain, Paquot and Kleinschmager (2006) to be an activity that encompasses the different modes and or means of transport and the routes used by them, which in turn form networks in and between cities as well as the various facilities that line the routes served by transport.

Therefore, transport allows the control of territories and contributes to its evolution and change by imposing arrangements to carry out this mobility which in turn takes place through all means of transport.

In the complexity paradigm, transport, like the territory, is a complex system, because in order to understand it, it is necessary to understand the functioning of its elements and its relations with the others. 
These sub-systems that make up the transport system interact, merge, interlock and juxtapose.

In the end, the road network, which represents the essential structure for travel, is both an essential component of the transport system and a major element of the territorial system that organises flows.

\section{The interaction between the two transport-territory systems:}

The study of the interaction between the transport system and the territorial system calls for a systemic study that will explain the direction of causalities between transport policies and land use.

The transport-urbanism relationship has existed for a long time, according to Marc Wiel in 1999, whose work explains the shape and size of cities by the speed adopted to get to the centre "the given size of the city, the balance of the urban system constantly associates density and speed". Moreover, multiple and intertwined issues existed between transport and urban planning; among these issues, those cited by Kaufmann in 2003.

The study of the literature shows the existence of a strong relationship between the spatial arrangement of the components of the territory and the forms of mobility, knowing that this study reveals, in the first place, a linear link in which the mode of transport shapes the territory and intervenes on its morphology. This linear link is due to the progress of technology, which has constantly transformed cities and their extension. Three types of cities have been defined to describe this co-evolution of urban form and modes of transport: the pedestrian city, the public transport city and the automobile city (Schaeffer and Sclar, 1975; Allaire, 2006).

Meanwhile, the relationship between modes of transport and urban morphology has changed from a linear link to a looping one, as Giovanni Fusco described it in 2003: "Allowed by the automobile, urban sprawl becomes its slave". This loop relationship is in fact a feedback loop, because "the city and mobility have an intimate relationship: modes of travel allow the mobility of individuals within a territory, but mobility depends on the characteristics of the city that supports it" (Fouchier, 2000), and there is "a reciprocal relationship whereby the urban layout adapts to the conditions of mobility, while mobility is the expression of the characteristics of the urban layout" (Wiel, 2002). The author explains the feedback loop by the spatial configuration which is at the same time the result of the automobile system by conditioning its hegemony, the same author reinforces his idea in 2006: "urban morphology and mobility pursue partially common goals: they interact with each other, they are complementary and/or competing, and in any case can never be dissociated from each other. The city conditions the forms of mobility as the conditions of mobility affect the shape of the city. We are dealing with a system that has the complexity of the living...". He explains that transport is like a living organism that is born, develops and is transformed by the progress of a network that is modified to adapt to the socio-economic needs that determine the territories.

The interaction between these two complex systems has been one of the questionable accounting in Anglo-Saxon and Francophone works through the notion of efficiency of the modes and means of transport existing on a given territory. Among these works, those of Peter Newman and Jeffrey Kenworthy in 1980 who demonstrate the existence of a strong link between urban density and the use of public transport (Newman, Kenworthy; 1989) according to their studies carried out on several cities in the world. Meanwhile, a second strong relationship, has been highlighted by numerous researchers including Jean-Christophe Foltête, Crille Genre-Grandpierre and Didier Josselin in 2008, exists between the morphology of the road network and travel modes and practices. In addition to the efficiency of modes and means of transport, the performance of these modes must be at the same discretion, with a proper sustainability, while respecting all three aspects of sustainable development.

Therefore, transport systems must induce sustainable mobility by engaging the different actors of the territories to rethink their mobility through the reduction of the use of the car by rebalancing the modal distribution.

In short, a good match between these two complex systems can only be envisaged through sustainable mobility. In 2005, GenreGrandpierre stated that: "in a context where environmental concerns are becoming increasingly important, at a time when urban travel plans are being drawn up which aim, at least theoretically, to achieve a more equitable modal split, detailed knowledge of non-automobile mobility and its determinants appears to be strategic in order to ensure its development". It should be remembered that today modal splits are more than important and, moreover, the factors of sustainable transport use seem relevant for an effective policy (Saint Amand, 2011).

In conclusion, the strong relationship between the territorial system and the transport system is exercised in terms of the configuration of the territories, as the latter is a determining factor in the efficient and efficient use of different modes and means of transport.

\section{Modelling models of transport network-territory interaction} for the development of indicators:

Since the 1990s, several professional and political actors specialised in urban planning and its problems have been denouncing that urban planning cannot be disconnected from transport policies, as they interact with each other forming a complex system.

The study of this complex system with its different relationships, interaction and feedback, is a global problem studied by the different LUTI (Land Use Transport Interaction) models. Models born in the United States are a classic scientific reference for taking into account the daily and residential mobility of an urban area. All the models propose different approaches, of which $\mathrm{M}$. Weggener (2004) notes common characteristics: "they offer a predictive or prospective approach to the future of transport infrastructures and their use, in relation to the form and expansion of housing and the human activities that result from them, and vice versa; they evaluate these projections in relation to the concrete objectives of sustainable development; they will play an increasing role in the future in the implementation and decision-making on economic, social and environmental investments" (Jean Philippe Antoni, 2018).

These interaction approaches between land use and transport are part of the disciplines of transport socio-economics and planning, of which we count and classify seventeen models, of which Chang in 2006, classifies them into: spatial interaction models, planning 
models based on operational research, microscopic random utility models and land market models.

Wegener and Fürst in 2004 set out a general theoretical and empirical framework for these LUTI interaction models in the form of a circular effect cycle between four concepts which are: land use, activity location, transport system and accessibility distribution (Figure 1):

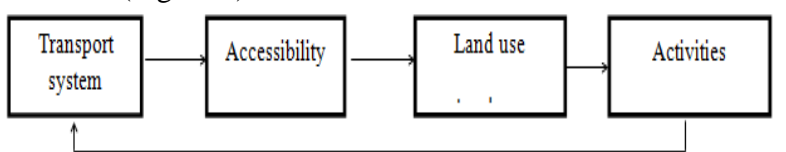

Figure 1. Circular effect between the concepts of LUTI models

From this loop, we will notice that the effects of the distribution of activities are those on the use of the transport system, which explains that they are related to mobility through: a modal choice, a frequency of trips and a length of trips. The expected theoretical effects are classified as follows according to Wegener and Fürst:

- $\quad$ Land use $\rightarrow$ Transport: minimum residential density is necessary for public transport efficiency, concentration of jobs implies longer travels, larger cities have a higher modal share for public transport.

- $\quad$ Transport $\rightarrow$ Land use: high accessibility implies higher prices and increased residential development, businesses locate for better accessibility to large-scale transport.

- $\quad$ Transport $\rightarrow$ Transport: places with good accessibility will produce more and longer travels, modal choice and transport cost are strongly correlated.

In sum, LUTI models are indeed approaches whose fundamental characteristics are, according to Raimbault in 2018:

- Understanding an evolution of a territory in the context of a given transport network,

- A logic of planning and applicability, being often involved themselves in decision making,

- An application to medium scales in space (metropolis) and time (decade).

Indeed, the implementation of a fit strategy of integrating urban issues into transport policies is essential, while relying on transversal public policies, because the problem of transport is not only the adequacy between transport supply and demand, but also to the development of a policy of citizen participation.
Therefore, the development of a sustainable mobility indicator set seems to be an important step in this strategy to operationalize the concept of sustainability. In this context, several incentive projects have tried to find indicators according to purpose, nature and context in order to achieve sustainability. The majority of these projects are inspired by the concept of sustainable development in order to find a definition for the notions of sustainable transport and mobility. The adopted and referenced definition of a sustainable transport system is the one given by the European Council of Transport Ministers in 2001 and which was used directly in the TERM (Transport and Environment Reporting Mechanism) Project: "a sustainable transport system (is) defined as one that :

- allows the basic access and development needs of individuals, companies and spcieties to be met safely and in a manner consistent with human and ecosystem health, and promotes equity within and between successive generations;

- $\quad$ is affordable, operates fairly and efficiently, offers choice of transport mode, and supports a competitive economy, as well as balanced regional development;

- $\quad$ limits emissions and waste within the planet's ability to absorb them, uses renewable resources at or below their rates of generation, and, uses non-renewable resources at or below the rates of development of renewable substitutes while minimising the impact on the use of land and the generation of noise.

The eleven projects that talk about sustainable mobility indicators are summarised in the table below (see table 2) in order to be well visualised according to their scale, nature and objectives.

\begin{tabular}{|c|c|c|c|c|c|c|}
\hline The project & Origin & Scale & Nature & Objectives & Development process & $\begin{array}{c}\text { Approximate } \\
\text { number of } \\
\text { indicators }\end{array}$ \\
\hline $\begin{array}{c}\text { TERM (Transport } \\
\text { and Environment } \\
\text { Reporting } \\
\text { Mechanism) }\end{array}$ & $\begin{array}{c}\text { The European } \\
\text { Environment } \\
\text { Agency (EEA) }\end{array}$ & $\begin{array}{c}\text { International } \\
\text { (European Union) }\end{array}$ & Policy & $\begin{array}{c}\text { Evaluation of member } \\
\text { countries' transport } \\
\text { policies }\end{array}$ & An evaluative approach & 31 \\
\hline $\begin{array}{c}\text { Integration of } \\
\text { environmental } \\
\text { concerns }\end{array}$ & $\begin{array}{c}\text { OECD } \\
\text { (Organisation for } \\
\text { Economic Co- } \\
\text { operation and } \\
\text { Development) }\end{array}$ & International & Policy & $\begin{array}{c}\text { Promoting the } \\
\text { integration of } \\
\text { environmental concerns } \\
\text { into transport policies } \\
\text { and decisions }\end{array}$ & Substantive approach & 13 \\
\hline $\begin{array}{c}\text { STPI (Sustainable } \\
\text { Transportation } \\
\text { Performance } \\
\text { Indicators) }\end{array}$ & $\begin{array}{c}\text { The Centre for } \\
\text { Sustainable } \\
\text { Transport (CST) }\end{array}$ & National (Canada) & Policy & $\begin{array}{c}\text { To provide a common } \\
\text { vision and definition of } \\
\text { a sustainable transport } \\
\text { system and to provide } \\
\text { the tools to measure }\end{array}$ & Procedural approach & 14 \\
\hline
\end{tabular}




\begin{tabular}{|c|c|c|c|c|c|c|}
\hline & & & & $\begin{array}{c}\text { progress in this } \\
\text { direction. An } \\
\text { informative objective } \\
\text { and a decision-making } \\
\text { tool }\end{array}$ & & \\
\hline Grand Toronto & $\begin{array}{l}\text { Christopher A. } \\
\text { KENNEDY }\end{array}$ & $\begin{array}{l}\text { Urban Mobility } \\
\text { (Toronto Urban } \\
\text { Area) }\end{array}$ & Academic & $\begin{array}{c}\text { Assessment of the } \\
\text { sustainability of a } \\
\text { transport system in an } \\
\text { urban area at a } \\
\text { macroscopic scale }\end{array}$ & Substantive approach & 10 \\
\hline $\begin{array}{l}\text { Liverpool } \\
\text { Ecological } \\
\text { Footprint }\end{array}$ & $\begin{array}{c}\text { Stockholm } \\
\text { Environment } \\
\text { Institute Biology } \\
\text { Department, } \\
\text { University of York }\end{array}$ & & Academic & $\begin{array}{c}\text { Assessment of the } \\
\text { environmental impact } \\
\text { of human mobility } \\
\text { using a simple indicator }\end{array}$ & $\begin{array}{c}\text { The indicator is } \\
\text { developed according to } \\
\text { the methodology } \\
\text { developed by } \\
\text { Wackernagel and Rees } \\
\text { applied to transport. }\end{array}$ & 1 \\
\hline PROSPECTS & $\begin{array}{c}\text { ITS (Institute for } \\
\text { Transport Studies) } \\
\text { UK } \\
\end{array}$ & Urban mobility & Expert & Decision Support Tool & Substantive approach & 80 \\
\hline PROPOLIS & $\begin{array}{c}\text { Kari LAUTSO, } \\
\text { consultant (Finland) }\end{array}$ & $\begin{array}{l}\text { Urban mobility } \\
\text { (urban area) }\end{array}$ & Expert & $\begin{array}{l}\text { Decision support tool } \\
\text { and evaluation of } \\
\text { integrated } \\
\text { transport/urban } \\
\text { planning policies for } \\
2020 \\
\end{array}$ & $\begin{array}{l}\text { Indicators constructed } \\
\text { by transport specialists: } \\
\text { substantive approach }\end{array}$ & 35 \\
\hline TRANSPLUS & $\begin{array}{c}\text { ISIS (Rome, Italy) } \\
\text { European research } \\
\text { programme }\end{array}$ & $\begin{array}{l}\text { Urban Mobility (25 } \\
\text { European cities) }\end{array}$ & Expert & $\begin{array}{l}\text { Decision support tool } \\
\text { and evaluation of the } \\
\text { success of policies } \\
\text { integrating transport } \\
\text { and urban planning } \\
\text { issues }\end{array}$ & $\begin{array}{l}\text { Substantive approach: } \\
\text { the experts proposed a } \\
\text { list of indicators } \\
\text { according to the } \\
\text { objectives of the } \\
\text { project. }\end{array}$ & 30 \\
\hline \begin{tabular}{|c|} 
Sustainable \\
mobility indicators: \\
application to the \\
Lyon conurbation
\end{tabular} & $\begin{array}{l}\text { LET (Transport } \\
\text { Economics } \\
\text { Laboratory) }\end{array}$ & $\begin{array}{c}\text { Urban mobility } \\
\text { (Lyon conurbation) }\end{array}$ & Academic & $\begin{array}{c}\text { To provide a measure } \\
\text { of the sustainability of } \\
\text { an urban transport } \\
\text { system. Informative and } \\
\text { evaluative objective }\end{array}$ & Substantive approach & 11 \\
\hline \begin{tabular}{|c|} 
Indicators for the \\
evaluation of urban \\
mobility scenarios \\
\end{tabular} & $\begin{array}{l}\text { INRETS-DEST } \\
\text { Caroline Gallez }\end{array}$ & Urban mobility & Academic & $\begin{array}{c}\text { Evaluation of urban } \\
\text { mobility evolution } \\
\text { scenarios }\end{array}$ & Substantive approach & 27 \\
\hline $\begin{array}{c}\text { Observatory of } \\
\text { urban travel plans }\end{array}$ & $\begin{array}{c}\text { CERTU (Centre } \\
\text { d'Etudes sur les } \\
\text { Réseaux, les } \\
\text { Transports, } \\
\text { l'Urbanisme et les } \\
\text { constructions } \\
\text { publiques) }\end{array}$ & $\begin{array}{c}\text { Urban mobility } \\
\text { (French urban areas } \\
\text { with more than } \\
\text { 100,000 inhabitants) }\end{array}$ & Policy & $\begin{array}{c}\text { Evaluation and control } \\
\text { of a public policy } \\
\text { (PDU) }\end{array}$ & Substantive approach & 251 \\
\hline
\end{tabular}

Table 2. The eleven sustainable mobility indicators projects

The nature of these projects is different and is either carried out by researchers in the case of academic projects in order to improve and understand sustainability, or carried out by public authorities specialised in transport in the case of administrative projects where the main objective is to steer transport and urban planning projects and policies; or developed by transport and environment experts as a decision support tool for transport policy-making. Indeed, it should be noted that all projects that attempt to set up a system of indicators insist on two important points: evaluation and the involvement of company (stakeholders).

\section{METHODOLOGY}

In the context of our work, we have had a broad overview of the different existing relations between two complex systems
(Territory / Transport) previously explained and developed, as well as an overview of the models that allow the study of interaction between these two systems, passing through the different disciplines and associated problems and the projects that initiate the indicator systems. At this stage of the study, it remains to find indicators that allow the adequacy between these two systems for the good management of the territory and its transport network in the present and the future.

Therefore, an epistemological and thematic study, based on scientific research, has been proposed as a complementary approach to the previous literature review, which will allow the elaboration of a set of indicators related to transport-territoryenvironment.

In order to do so, we have collected as much information as possible on the projects initiating indicator systems, synthesised 
them and commented on them in order to draw out the indicators that can be adopted for our context and that are related to transport-territory-environment.

Speaking about the context of study, Algiers is considered as a complex and paradoxical territory with several constraints, formerly historical and constantly geomorphological. These challenges affect precisely the spatial organisation of the city and consequently its transport network, creating traffic difficulties that stem from the morphology and structure of its site and its history (Merrad-Benyamina, 2019), social disparities between the eastern and western parts of the city, an imbalance in transport supply and demand, polycentricity, urban sprawl due to the topographical nature and relief that characterises the site of Algiers.

The city of Algiers, like any other city in the Mediterranean, is known for its rich and complex territory. This geological nature and this strategic position in the Mediterranean gave the city a very adapted urban structure and a complex transport network. To this end, the use of a set of sustainable mobility indicators will allow a better match between its complex territorial and transport system in order to solve its transport and travel problems in general and improve its status as a metropolis.

The following diagram explains the working protocol adopted to reach our objective which is the elaboration of the set of indicators allowing the adequacy between the two complex systems (Territory/Transport) at the level of our case study (Algiers).

Below is the working protocol (see diagram 1) followed for the elaboration of the set of indicators of sustainable mobility which will allow the adequacy between the territorial system of Algiers and its complex transport network.

\section{RESULTS AND DISCUSSION}

According to the analysis of the literature, the adequacy between territorial system and transport system, can be carried out by strengthening and working on two links:

- A first link in relation to the territorial system and which is in interaction with the transport system, this link is constituted by the elementary components which are: the relief, the density of the population, the type of habitat and the distribution of the activities.

- A second link in relation to the transport system and which interacts with the territorial system, this link is made up of the following elementary components: relief, population density, type of housing and distribution of activities: the form of the road network, the supply and demand for transport, the modal split and whether or not there are plans for sustainable mobility

Therefore, the link between the components of these two systems will consider the use of sustainable mobility, as an effective and efficient mobility is perfectly adapted to its territory. Therefore, the search for indicators for this sustainable mobility will allow us to better adapt our transport network in our case study.

The detailed study of the indicators of each project will be detailed in the table 3 .

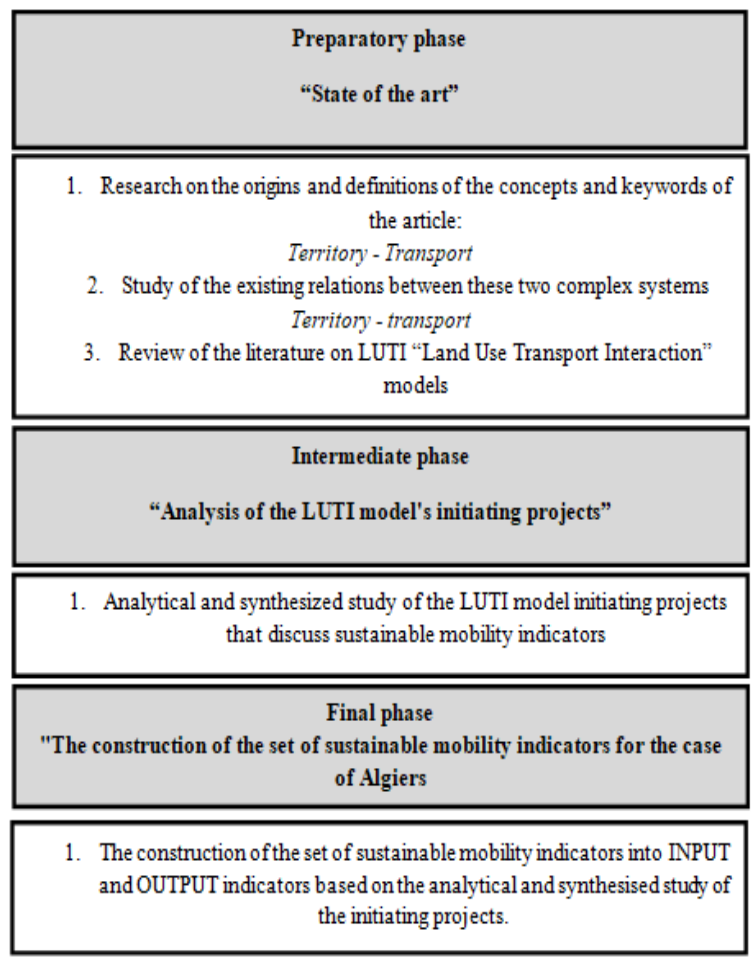

Diagram 1. Working protocol for the development of the sustainable mobility indicator set 


\begin{tabular}{|c|c|}
\hline The Project & Indicators \\
\hline $\begin{array}{l}\text { TERM (Transport and } \\
\text { Environnement } \\
\text { Reporting Mechanism) }\end{array}$ & 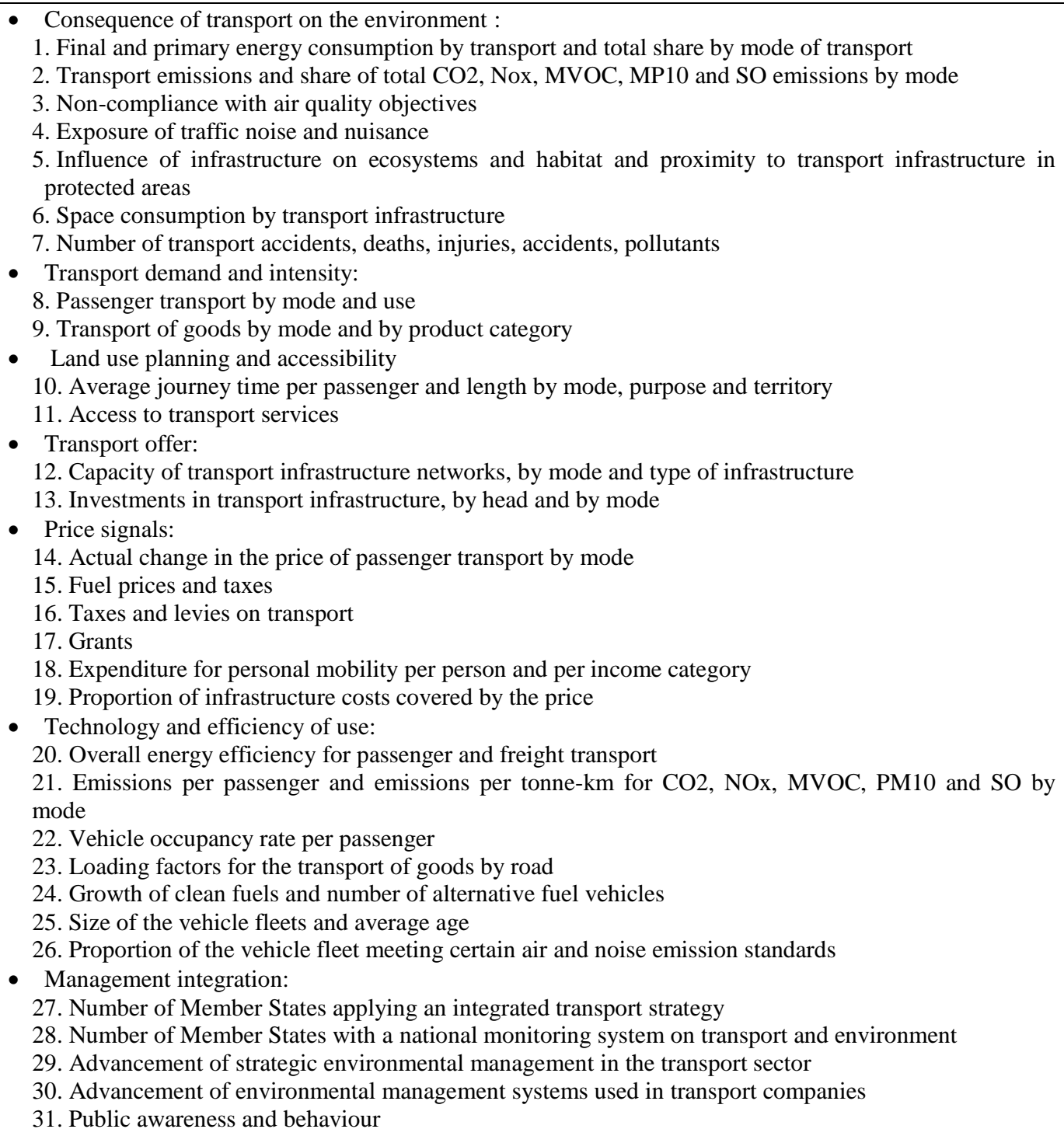 \\
\hline $\begin{array}{l}\text { Indicators for } \\
\text { integrating } \\
\text { environmental } \\
\text { concerns into transport } \\
\text { policies }\end{array}$ & $\begin{array}{l}\text { - Traffic: } \\
\text { 1. Passenger transport by mode } \\
\text { 2. Freight transport by mode } \\
\text { 3. Volume and intensity of road traffic } \\
\text { - Infrastructures: } \\
\text { 4. Length and density } \\
\text { - Vehicle: } \\
\text { 5. By automobile } \\
\text { 6. Composition of the road vehicle fleet } \\
\text { - Energy use: } \\
\text { 7. Final energy consumption by mode } \\
\text { 8. Land transport fuel consumption by fuel type } \\
\text { - Air pollution: } \\
\text { 9. Emissions directly linked to transport } \\
\text { 10. Road transport emissions } \\
\text { 11. Trends in CO2emissions } \\
\text { - Risks and safety: } \\
\text { 12. Number of accidents } \\
\text { Signals and prices }\end{array}$ \\
\hline
\end{tabular}




\begin{tabular}{|c|c|}
\hline & 13. Taxes and fuels \\
\hline $\begin{array}{l}\text { STPI (Sustainable } \\
\text { Transportation } \\
\text { Performance } \\
\text { Indicators) }\end{array}$ & $\begin{array}{l}\text { 1. Use of energy for all transport } \\
\text { 2. Greenhouse gas emissions for all transport } \\
\text { 3. Emission index of atmospheric pollutants emitted by road transport } \\
\text { 4. Indices of deaths and injuries caused by the transport system } \\
\text { 5. Intensity of passenger traffic : the number of person-kilometers in motorized transport } \\
\text { 6. Freight intensity : total motorized freight movement across Canada in tonne-kilometers } \\
\text { 7. Share of motorized trips (\%) made other than by public transport } \\
\text { 8. Transport vehicle trips :number of vehicle kilometers (in billions) } \\
\text { 9. Urban space used per city dweller ( } 2 \text { per inhabitant) } \\
\text { 10. Length of paved roads (in thousands of two-line equivalent kilometers) } \\
\text { 11. Cost of transport for households (\% of the budget dedicated to transport after taxes) } \\
\text { 12. Index of the relative cost of urban public transport } \\
\text { 13. Energy intensity index (energy used per unit of distance) } \\
\text { 14. Emission intensity index (emission per unit of energy used, based } 100 \text { in 1990) }\end{array}$ \\
\hline $\begin{array}{l}\text { A comparison of the } \\
\text { sustainability of public } \\
\text { and private } \\
\text { transportation systems: } \\
\text { study of the grater } \\
\text { Toronto Area }\end{array}$ & $\begin{array}{l}\text { Economic indicators : } \\
\text { 1. Number of kilometers traveled daily } \\
\text { 2. Income of all housholds in Toronto } \\
\text { 3. Weight of the transport industry in the activity of the urban area: number of jobs, turnover } \\
\text { 4. Transport costs (public and private): average mileage per inhabitant, number of trips average cost per } \\
\text { trip, total cost per day, cost per passenger.km } \\
\text { Environmental indicators: } \\
\text { 5. Annual emissions (in kg) per capita due to transport: } \mathrm{CO} 2, \mathrm{NOX}, \mathrm{SO} 2, \mathrm{CO}, \mathrm{VHC}, \mathrm{VP} \\
\text { 6. Estimates of the health effects of pollutant emissions from transport: number of premature deaths per } \\
\text { year, number of hospital admissions per year } \\
\text { 7. Energy consumption by mode in MJ/person.km, MJ/seat.km, Mj/veh.km } \\
\text { Social indicators: } \\
\text { 8. Service levels average travel speed by mode, travel time } \\
\text { 9. Accidentology: number of deaths and injuries per year, cost (insurance, rescue, etc.) of accidents } \\
\text { 10. Employments: number and nature of jobs related to the automotive industry }\end{array}$ \\
\hline $\begin{array}{l}\text { Sustainable mobility } \\
\text { indicators: application } \\
\text { to the Lyon } \\
\text { metropolitan area }\end{array}$ & $\begin{array}{l}\text { - Mobility : the service provided: } \\
\text { 1. Reasons and number of daily trips } \\
\text { 2. Modes used, distances traveled, speeds and daily travel times } \\
\text { - Environmental dimension indicators: } \\
\text { 3. Unit emissions }(\mathrm{g} / \mathrm{km}) \text { of } \mathrm{CO} 2, \mathrm{CO}, \mathrm{NOx} \text {, Hydrocarbons and particles of the various modes } \\
\text { considered, petrol passenger cars, diesel passenger cars, buses, motorized two-wheelers, walking, } \\
\text { bicycle } \\
\text { 4. Unit space consumption of these same modes, at rest }(\mathrm{m} 2) \text { and in circulation (m2.H) } \\
\text { 5. The average distances }(\mathrm{km}) \text { per person and per day of the week, traveled within the study area for } \\
\text { each mode } \\
\text { Economic dimension indicators: } \\
\text { 6. average overall cost of a passenger-kilometer } \\
\text { 7. Annual cost of a person's mobility } \\
\text { 8. Total annual expenditure level according to the actors (households, community, etc.) and modes (PV, } \\
\text { TC) } \\
\text { Social dimension indicators: } \\
\text { 9. Motorization indicators (motorization rate) } \\
\text { 10. Indicators characterizing the length of trips with regard to the sociological and economic } \\
\text { determinants of households (budgets-distance all modes or broken down by mode or by reason) } \\
\text { 11. Income per consumption unit and the percentage of income devoted to expenditure on urban } \\
\text { transport }\end{array}$ \\
\hline $\begin{array}{l}\text { Urban mobility } \\
\text { evolution scenario } \\
\text { assessment indicators }\end{array}$ & $\begin{array}{ll}\text { - } & \text { Individuals, households: } \\
\text { 1. Number of trips } \\
\text { 2. } \\
\text { 3. } \text { Tistance budget } \\
\text { 4. } & \text { Average speed } \\
\text { 5. } & \text { Travel chaining rate } \\
\text { 6. } & \text { Transport energy budget } \\
\text { 7. } & \text { Pollutant emission budgets } \\
\text { 8. } & \text { Space consumption } \\
\text { 9. } & \text { Transport monetary budget }\end{array}$ \\
\hline
\end{tabular}




\begin{tabular}{|c|c|}
\hline & $\begin{array}{l}\text { 10. Budget coefficient of travel } \\
\text { 11. Breakdown of fixed costs / variable cost } \\
\text { 12. Contribution of taxes in the total cost } \\
\text { 13. Access to modes } \\
\text { 14. Accessibility to jobs, services, shops } \\
\text { - Travel market: } \\
\text { 15. Breakdown of the number of trips } \\
\text { 16. Spatial distribution of traffic } \\
\text { 17. Energy balance } \\
\text { 18. Pollutant emissions reports } \\
\text { 19. Spaces consumed } \\
\text { 20. Total expenses for travel } \\
\text { 21. Tax income } \\
\text { 22. Betting of expenditure between public and private } \\
\text { 23. Accessibility indicators at a given point } \\
\text { 24. Characteristics of the distribution of traffic according to user categories } \\
\text { 25. Social disparities in the rate of exposure to nuisances } \\
\text { 26. Indicators of redistribution of tariff policies or taxes } \\
\text { 27. Social disparities in accessibility to a type of equipment or to a given area }\end{array}$ \\
\hline $\begin{array}{l}\text { Observatory of urban } \\
\text { travel plans }\end{array}$ & 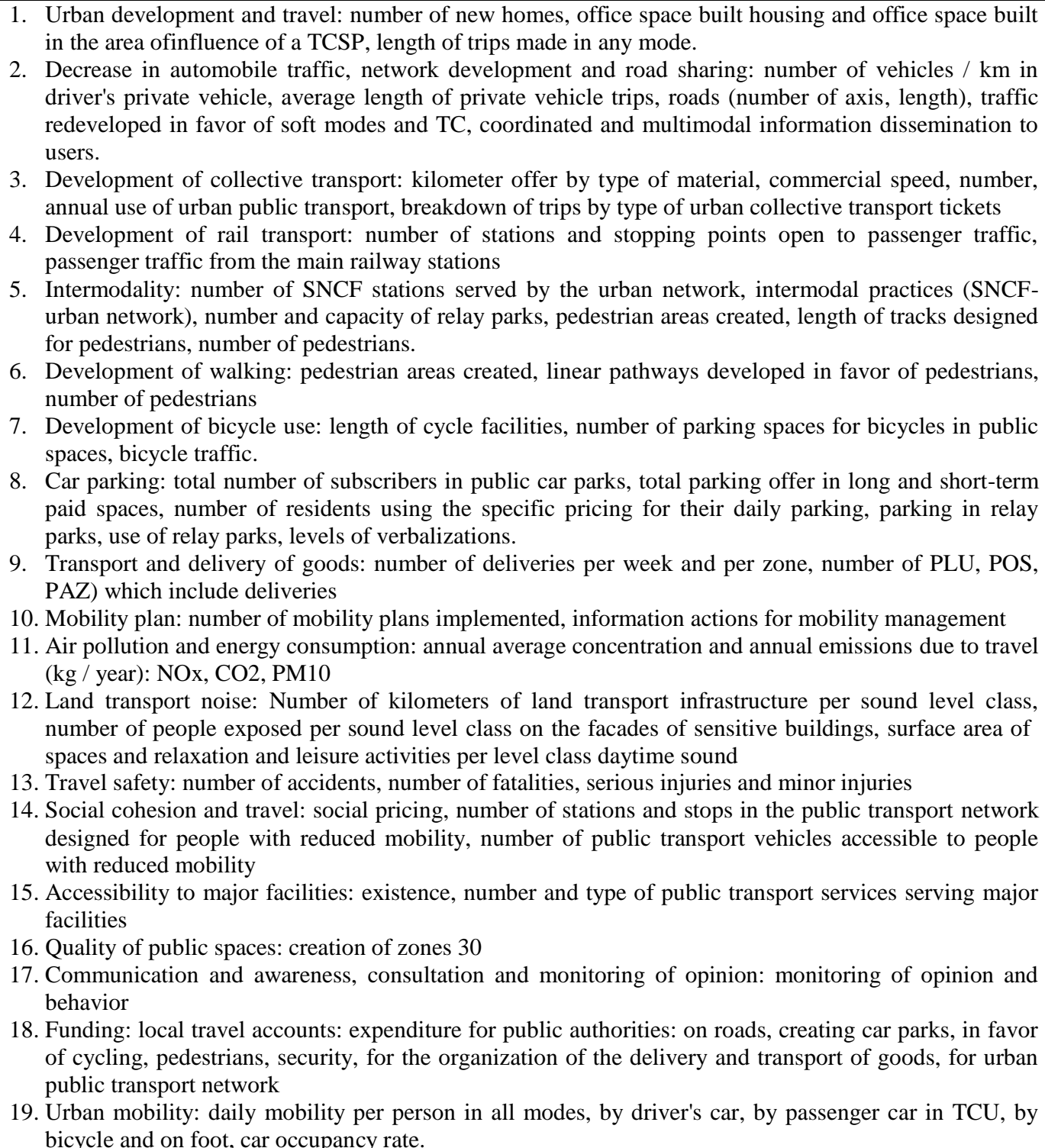 \\
\hline
\end{tabular}




\begin{tabular}{|c|c|}
\hline $\begin{array}{l}\text { PROSPECTS } \\
\text { (Procedures for } \\
\text { Recommending } \\
\text { Optimal Sustainable } \\
\text { Planning of European } \\
\text { City Transport Systems }\end{array}$ & 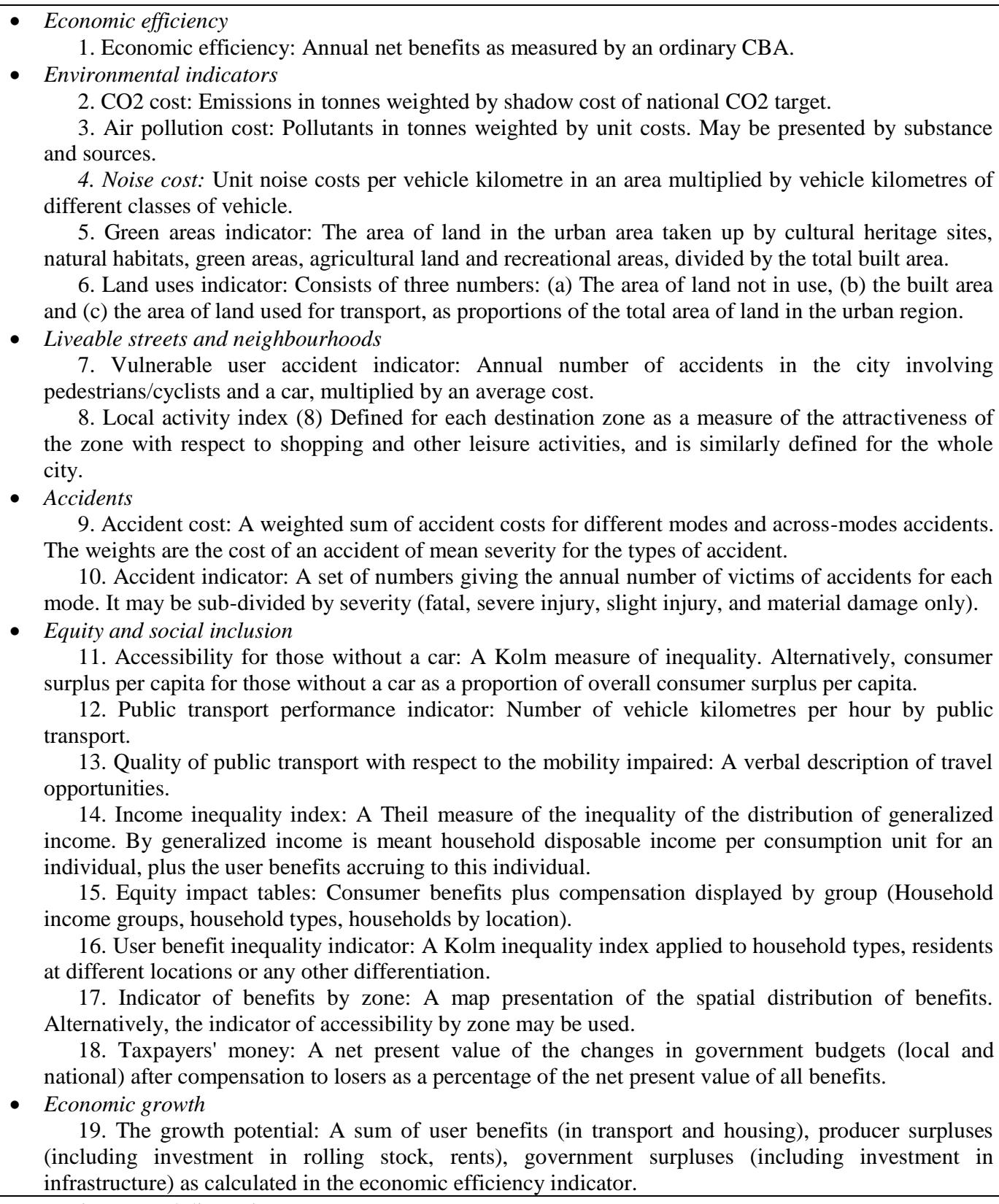 \\
\hline $\begin{array}{l}\text { PROPOLIS (Planning } \\
\text { and Research of } \\
\text { Policies for Land Use } \\
\text { and Transport for } \\
\text { Increasing Urban } \\
\text { Sustainability) }\end{array}$ & $\begin{array}{l}\text { - Environmental dimension: } \\
\text { Climate change (CO2 equivalent per thousand inhabitants per year): } \\
\text { 1. Greenhouse gas emissions from transport } \\
\text { 2. Greenhouse gas emissions due to town planning } \\
\text { Air pollution: (equivalent tonnes per thousand inhabitants per year) } \\
\text { 3. Acid gas emissions due to transport } \\
\text { 4. Emission of volatile organic compounds } \\
\text { Consumption of natural resources: } \\
\text { 5. Consumption of fossil fuels due to transport (ton / } 1000 \text { inhabitants / year) } \\
\text { 6. Space consumed (\% space) } \\
\text { 7. Space requirements for new constructions (annual growth in\%) } \\
\text { Environmental quality: } \\
\text { 8. Fragmentation of natural space (index) } \\
\text { 9. Quality of the natural space (index) } \\
\text { - Social dimension: } \\
\text { Health: }\end{array}$ \\
\hline
\end{tabular}




\begin{tabular}{|c|c|}
\hline & $\begin{array}{l}\text { 10. Exposure to particles emitted by transport (\% of the population) } \\
\text { 11. Exposure to nitrogen dioxide emitted by transport ( } \% \text { of the population) } \\
\text { 12. Exposure to noise pollution caused by traffic ( } \% \text { of the population) } \\
\text { 13. Number of fatalities in road accidents (number of fatalities / 1,000,000 inhabitants / year) } \\
\text { 14. Number of injured (number of injured / 1,000,000 inhabitants / year) } \\
\text { Equity: } \\
\text { 15. Justice in the distribution of economic benefits (index) } \\
\text { 16. Justice of exposure to particles (hint) } \\
\text { 17. Justice of exposure to noise (hint) } \\
\text { 18. Segregation (GINI index) } \\
\text { Opportunities: } \\
\text { 19. Standard housing supply (\% overcrowded housing) } \\
\text { 20. Vitality of the city center (index) } \\
\text { 21. Vitality of the peripheral region (index) } \\
\text { 22. Productivity gain brought about by urban planning management (\% / year) } \\
\text { Accessibility and traffic: } \\
\text { 23. Total time spent in transport (hours / inhabitants / year) } \\
\text { 24. Level of public transport services (minutes / trips) } \\
\text { 25. Accessibility to the city center (minutes / trips) } \\
\text { 26. Accessibility to services (minutes / trips) } \\
\text { 27. Accessibility to green spaces (minutes / trips) } \\
\text { - Economic dimension: } \\
\text { Total net benefit from transport: } \\
\text { 28. Benefits of transport users (Euro / inhabitant) } \\
\text { 29. Benefits of transport operators (Euro / inhabitant) } \\
\text { 30. Government benefits related to transport (Euro / inhabitant) } \\
\text { 31. Generalized transport costs (Euro / inhabitant) } \\
\text { 32. Costs of transport investments (Euro / inhabitant) } \\
\text { 33. External costs linked to transport accidents (Euro / inhabitant) } \\
\text { 34. External costs linked to the emission of pollutants (Euro / inhabitant) } \\
\text { 35. External costs linked to greenhouse gas emissions (Euro / inhabitant) } \\
\text { 36. External costs linked to noise pollution (Euro / inhabitant) } \\
\text { Total benefit linked to town planning: } \\
\text { 37. Variation in the price of living space (Euro / inhabitant) } \\
\text { (1) }\end{array}$ \\
\hline $\begin{array}{l}\text { TRANSPLUS } \\
\text { (Transport Planning } \\
\text { Land-Use and } \\
\text { Sustainability) }\end{array}$ & $\begin{array}{l}\text { - Output Indicators: } \\
\text { 1. PT lineage by area } \\
\text { 2. Land uses within X meters from PT stops } \\
\text { 3. PT operator costs } \\
\text { 4. PT subsidies } \\
\text { 5. Pedestrian and cycling reserved area } \\
\text { 6. Retail, office, service facilities / housing available floor space ratio } \\
\text { 7. Retail, office, service facilities / housing occupied floor space ratio } \\
\text { 8. Non motorised modes modal share } \\
\text { 9. Limited/priced access zones } \\
\text { 10. Limited/priced car parking places } \\
\text { 11. Private car parking space } \\
\text { 12. Road traffic } \\
\text { 13. Car modal share } \\
\text { 14. Vehicule occupancy } \\
\text { 15. Average car journey length and time } \\
\text { 16. Congestion severity index } \\
\text { 17. Car user costs } \\
\text { - Result indicators: } \\
\text { 18. Use of brownfield land for new housing and non-residential uses } \\
\text { 19. Density of mixed-uses within towns } \\
\text { 20. Polynuclears development of metropolitan areas and region } \\
\text { 21. Car ownership } \\
\text { 22. Accessibility } \\
\text { 23. Total travel volume per capita } \\
\text { 24. Total travel volume per passenger } \\
\text { 25. Total travel time per capita }\end{array}$ \\
\hline
\end{tabular}




\begin{tabular}{|l|l|}
\hline & 26. Total travel time per passenger \\
& 27. Change in number of residents \\
& 28. Change in number of households \\
& 29. Change of number of accidents and deaths/injured people \\
30. Change of population exposure to health harmful effects & 31. Change of employment \\
& 32. Social exclusion \\
33. Change of energy consumption \\
34. Change of air quality \\
35. Change of exposure to noise \\
The Ecological & 36. Change of quality of housing and other building stocks \\
Transport in & 1. Change of availability/accessibility to green areas \\
Merseyside & \\
\hline
\end{tabular}

Table 3. Projects

A first reading of the summary table (table 3 ) of the different projects shows that a certain number of indicators are similar in all projects, namely: energy consumption, road safety and health, environment and pollution, financial cost and taxes, modal choice of transport. Moreover, the units of measurement differ and vary according to the nature of the project and its objective. Indeed, all that has been studied in the different projects are the externalities of transport in particular.

We also note that the indicators relate to the services provided, the costs and the nuisances of travel within a given territory and that they are based on the three aspects of sustainable development (economic, social and environmental). In this same framework, accessibility was chosen as the main and central concept for the study of the services provided.

Accessibility has been translated by these indicators into two types: the first economic, associating accessibility to

Indeed, the indicators to be retained in the framework of our research will be classified according to the results obtained from the thematic analysis of the state of the art, namely the transport-territory-environment relationship and sustainable mobility, which has been considered as an important vector that allows the adequacy between the two complex systems.

Consequently, and after studying the previously defined project indicators, we will try to draw three categories of indicators (a first one related to the territory, a second one related to employment, shops, services and economic activities; and the second social, through the distinction according to a typology of people (budget, expenses, distances).

In terms of urban planning/transport interaction, we note that the indicators were associated with the location of activities, the location of the population and mobility indicators at a global level, namely the average time and distance budget/day/person, the flow and the number of travel.

In sum, the indicators related to accessibility are INPUT indicators because they allow the production of a service in this transport/urban interface. On the other hand, the OUTPUT indicators are generally the costs induced by this same interface and include the various gas emissions, energy and space consumption by transport, the costs of mobility felt by the various actors and finally the costs of transport according to the actors' income.

transport and a third one related to sustainable mobility), firstly to ensure the good adequacy between the two complex systems and secondly to be able to evaluate the current and future transport policies. This categorisation of indicators corresponds mainly to the principles of elaboration of indicators in the projects studied, namely Input indicators related to accessibility and Output indicators related to induced costs.

The table below (see Table 4) groups the indicators selected for our study into three categories.

\begin{tabular}{|l}
\hline \multicolumn{6}{|l|}{ Indicators to be adopted that enable the adequacy between the two systems and the evaluation of transport policies by public } \\
actors
\end{tabular}




\begin{tabular}{|c|c|c|}
\hline 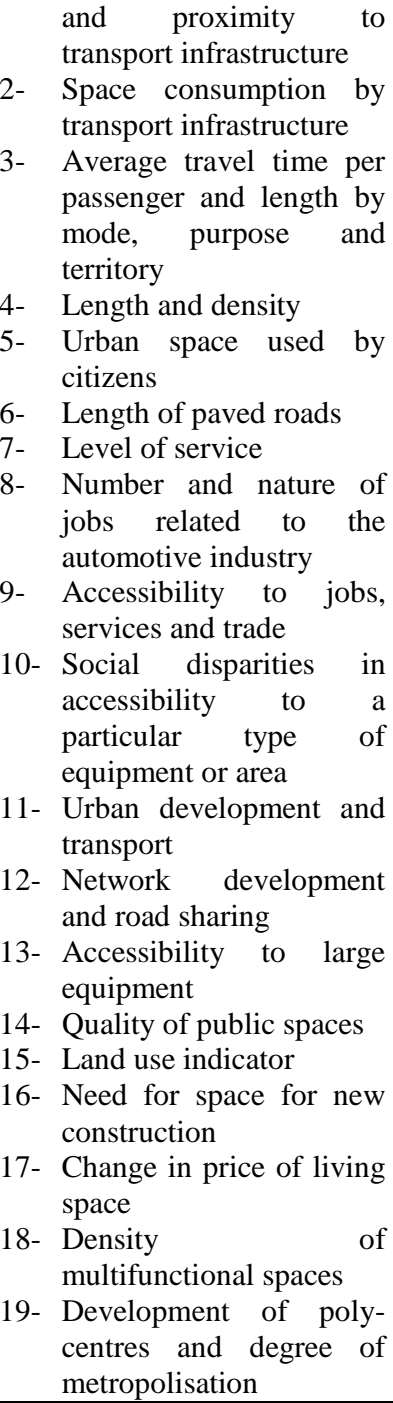 & 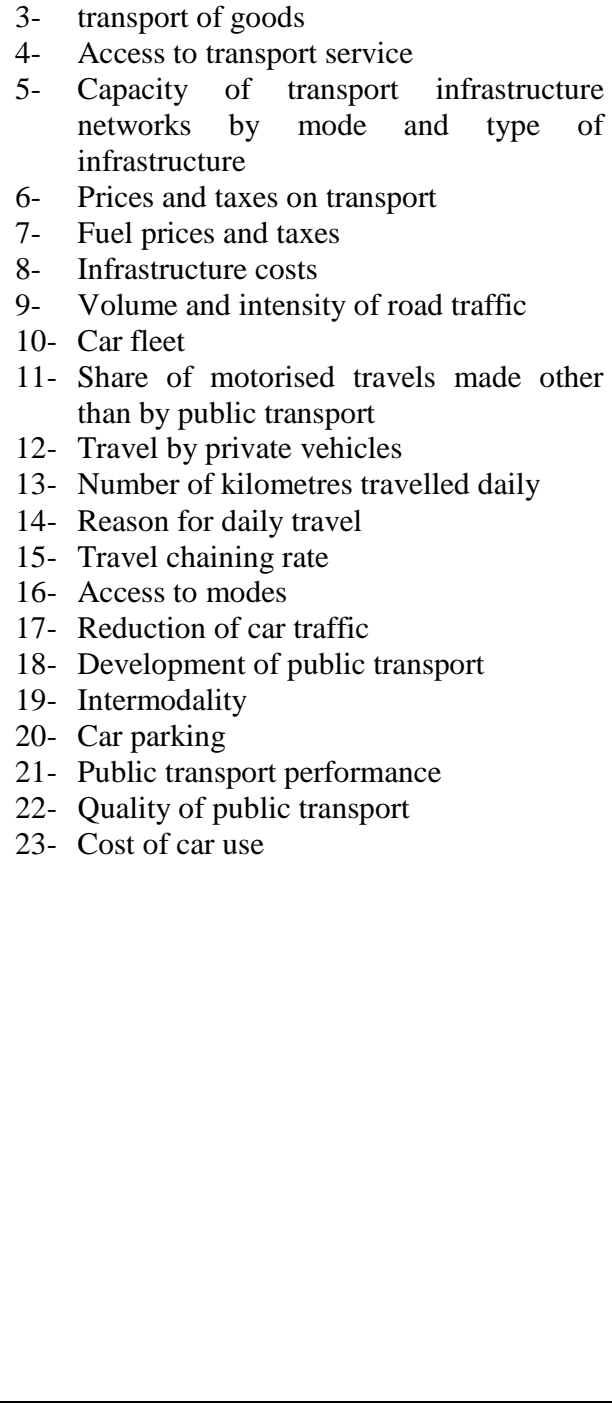 & $\begin{array}{ll} & \text { CES } \\
\text { 3- } & \text { Noise pollution } \\
\text { 4- } & \text { Public awareness and behaviour } \\
\text { 5- } & \text { Transport fuel consumption by } \\
& \text { fuel type } \\
\text { 6- } & \text { Development of walking } \\
\text { 7- } & \text { Development of bicycle use } \\
\text { 8- } & \text { Mobility plan } \\
\text { 9- } & \text { Social cohesion and mobility } \\
\text { 10- } & \text { Green space indicators } \\
\text { 11- } & \text { Fragmentation of natural space } \\
\text { 12- } & \text { Quality of natural space } \\
\text { 13- } & \text { The ecological footprint of } \\
\text { transport by mode. }\end{array}$ \\
\hline
\end{tabular}

Table 4. Sustainable mobility indicators for matching the two complex systems Territory-Transport

Through this study, we have attempted to retain 55 indicators, of which 19 are related to the territory, 23 to transport and 13 to sustainable mobility. In order to facilitate the reading and to follow the same logic of elaboration of indicators followed by the previous projects, we will group them into Input and Output indicators in the table below (see table 5).

\begin{tabular}{|c|c|c|}
\hline & INPUT indicators & OUTPUT indicators \\
\hline $\begin{array}{l}\text { In relation to the } \\
\text { territory }\end{array}$ & 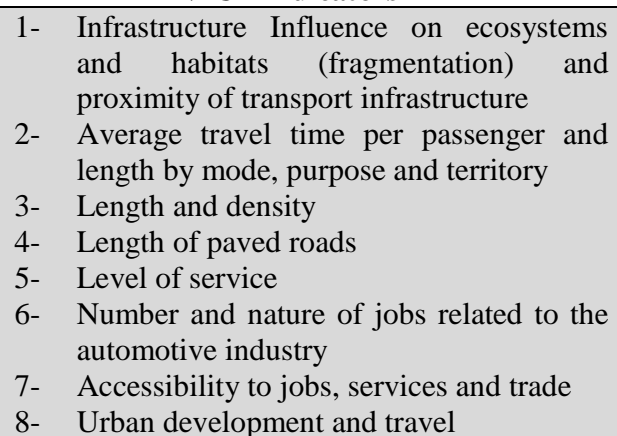 & $\begin{array}{ll}\text { 1- } & \text { Consumption of space by transport } \\
\text { infrastructure } & \\
\text { 2- } & \text { Urban space used by city dwellers } \\
\text { 3- } & \text { Social disparities in accessibility to a } \\
\text { particular type of equipment or area } \\
\text { 4- Need space for new construction } \\
\text { 5- Variation in the price of living space } \\
\text { 6- The development of poly-centres and the } \\
\text { degree of metropolisation. }\end{array}$ \\
\hline
\end{tabular}




\begin{tabular}{|c|c|c|}
\hline & 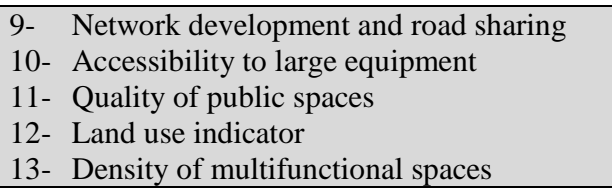 & \\
\hline $\begin{array}{l}\text { In relation to } \\
\text { transport }\end{array}$ & $\begin{array}{ll}\text { 1- } & \text { Passenger transport by mode and use } \\
\text { 2- } & \text { Freight transport } \\
\text { 3- } & \text { Access to transport service } \\
\text { 4- } & \text { Capacity of transport infrastructure } \\
\text { networks by mode and type of } \\
\text { infrastructure } \\
\text { 5- Reason for daily commuting } \\
\text { 6- } \\
\text { 7- } & \text { Access to modes } \\
\text { 8- } & \text { Intermodality } \\
\text { 9- } & \text { Car parking }\end{array}$ & $\begin{array}{ll}\text { 1- } & \text { Health and safety (number of road accidents } \\
\text { and illnesses due to transport) } \\
\text { 2- } \\
\text { 3- } \text { Frices and taxes on transport } \\
\text { 4- } \text { Infrastructure costs } \\
5-\quad \text { Volume and intensity of road traffic } \\
\text { 6- vehicle fleet } \\
\text { 7- Share of motorized travel other than by } \\
\text { 8- } \quad \text { Travel of private vehicles } \\
\text { 9- the number of daily kilometres driven } \\
\text { 10- Reduction of car traffic } \\
\text { 11- Development of public transport } \\
\text { 12- Public transport performance } \\
\text { 13- Quality of public transport } \\
\text { 14- } \text { Cost of car use }\end{array}$ \\
\hline $\begin{array}{l}\text { In relation to } \\
\text { sustainable mobility } \\
\text { and } \\
\text { environment }\end{array}$ & & $\begin{array}{ll}1- & \text { Energy consumption by transport } \\
\text { 2- } & \text { Emissions from transport in CES } \\
\text { 3- } & \text { Noise pollution } \\
\text { 4- } & \text { Public awareness and behaviour } \\
\text { 5- } & \text { Transport fuel consumption by fuel type } \\
\text { 6- } & \text { Development of walking } \\
\text { 7- } & \text { Development of bicycle use } \\
\text { 8- } & \text { Mobility plan } \\
\text { 9- } & \text { Social cohesion and mobility } \\
\text { 10- } & \text { Green space indicators } \\
\text { 11- } & \text { Fragmentation of natural space } \\
\text { 12- } & \text { Quality of natural space } \\
\text { 13- } & \text { The ecological footprint of transport by } \\
& \text { mode. }\end{array}$ \\
\hline
\end{tabular}

Table 5. INPUT and OUTPUT indicators of sustainable mobility

From the above table (table 5), classifying the INPUT and OUTPUT indicators, we notice that the number of OUTPUT indicators is 33, a number higher than the INPUT indicators which is 22 , this explains that the sustainable mobility indicators have more consequences on the territory and accessibility, namely that the indicators that are related to sustainable mobility and the environment are all OUTPUT indicators.

\section{CONCLUSION}

Algiers is a particular city by its Mediterranean territory which is complex and constantly becoming more complex by its urban development. The latter, also has a system and network of transport complex to address these various problems. And in spite of, the traffic problems in Algiers remains one of the priorities of the metropolis, hence the search of indicators for the adequacy between these two systems remains one of the solutions for a better management and planning present and future of the city.
To conclude, the set of synthetic indicators retained from this study has taken into account the multidimensionality of the approach and will attempt at present and in the future to ensure the adequacy between the two complex systems that Algiers knows and mainly the evaluation of the current and projected transport policies on the Algerian territory.

The indicators found are indicators of sustainable mobility that provide effectiveness and efficiency for the transport network in its territory and according to the results obtained, we found three categories of indicators:

- Indicators linked to the territory and interacting with the transport network, and which are directly related to the relief, the population density, the type of housing and the distribution of activities. The latter are more related to accessibility than to the costs incurred by the latter, that is, indicators of which the majority are OUTPUT indicators. 
- Indicators related to transport and interacting with the territory, and which are directly related to the form of the road network, transport supply and demand and modal split. These indicators are also indicators related to accessibility, that is, INPUT indicators, but the majority are OUTPUT indicators.

- Indicators of sustainable mobility in interaction with transport, the territory and the environment, which are all OUTPUT indicators representing the costs incurred by these interactions between the different systems.

\section{References}

ALLAIRE J, 2006, "Choisir son mode de ville, Formes urbaines et transports dans les villes émergentes », in Cahiers de global chance, $n^{\circ} 21$ - Mai 2006, 9 pages.

AURIAC F, 1984, Système économique et espace, éd. Economica, Paris, pp.196-200.

BRUNET R, 1990, Géographie Universelle « Mondes nouveaux », éd. Hachette / Reclus, 550 pages.

CHAPELON L, 1998-2000, «Réseau, accessibilité, flux, graphe, connexité », in GDR Libergéo, HyperGéo : encyclopédie électronique consacré à l'épistémologie de la Géographie.

CHANG, Justin S, 2006, Models of the Relationship between Transport and Land-use: A review. Transport Review 26.3, p. 325-350.

CHESNAIS M, 1980, Transports et espace français, éd. Masson, coll . Géographie, 212 pages.

CORBOZ A, 1983, Le territoire comme palimpseste.

DI MEO G, 1998, Géographie sociale et territoires, Paris, Nathan, 317 pages.

ELISSALDE B, 2002, «Une géographie des territoires », in L’information géographique, 65,3, pp.193-205.

Fiori S \& MAGNAGHI A, 2018, « Les territoire du commun. Entretien avec Alberto Magnaghi », Métropolitiques.

FOUCHIER V, 2000, in la forme des villes : caractériser l'étalement urbain et réfléchir à de nouvelles modalités d'actions, Séminaire de prospective urbaine, 180 pages.

FUSCO G, 2003, Un modèle systémique d'indicateurs pour la durabilité de la mobilité urbaine: les cas de Nice et Gênes dans une comparaison internationale, Thèse de Doctorat de Géographie, Université de Nice Sophia Antipolis / Politecnico di Milano, 728 pages.

GENRE-GENPIERRE C, 2005, Qualité de l'offre et usage du transport public en milieu urbain, SAGEO 2005, 18 pages.
In short, the set of indicators developed in this research will allow, through the first two categories of indicators, the study of the good adequacy between the transport system and the territorial system; and the study of the effectiveness and efficiency of urban mobility through the third category of indicators. In addition, the INPUT indicators are used in the study phase for the adequacy of the systems and the OUTPUT indicators for the final study or monitoring of the projects.

KAUFMANN V, JEMELIN C, 2003, «Articulation entre urbanisme et transport : quelles marges de manœuvre ? », in Revue internationale des sciences sociales $2003 / 2, n^{\circ} 176$, p. 329-340.

LE BERRE M, 1992, «Territoires », in Encyclopédie de Géographie, éd Economica, Paris, pp. 601-622.

MERRAD BENYAMINA B, 2019, Déplacements et mutations spatiales à Alger, Thèse de Doctorat en Géographie et Aménagement.

MOINE A, 2006, «Le territoire comme un système complexe : un concept opératoire pour l'aménagement et la géographie ", in L'espace géographique $n^{\circ} 2 / 2006$, pp.115132.

MOINE A, 2008, Le territoire: comment observer un système complexe, éd l'Hamattan, coll. Itinéraires géographiques, 176 pages.

NEWMAN P, KENWORTHY J-R, 1989, Cities and automobile Dependence. An international source book, Gower Technical, Sidney.

NORMAND D, 1996, Dictionnaire de l'Ancien Régime, Paris, PUF.

PAQUOT T, 2011, Qu'est-ce qu'un territoire ?, Vie Sociale $\mathrm{Vn}^{\circ} 2, \mathrm{~N}^{\circ} 2,23$ pages.

PUMAIN D, PAQUOT T, KLEINSCHMAGER R, 2006, Dictionnaire de la ville et de l'urbain, Paris, EconomicaAnthropos.

RAFFESTIN C, 1986, «Ecogenèse territoriale et territorialité » in AURIAC F et BRUNET R (éd), Espaces, jeux et enjeux, pp.173-185.

RAIMBAULT A, 2018, Caractérisation et modélisation de la co-evolution des réseaux de transport et des territoires, Thèse de doctorat en géographie de l'université Sorbonne Paris cité et préparée à l'université Paris Diderot.

ROLAND-MAY C, 2000, Evaluation des territoires: concepts, modèles, méthodes, éd. Hermès, 381 pages. 
SAINT-AMAND P, 2011, L'adéquation d'un système de transport aux systèmes territoriaux méditerranéens : pour une mobilité durable. Modélisation et aide à la décision, thèse de doctorat.

SCHAFFER K, SCLAR E, 1975, Access for all: transportation and urban growth, Penguin Books, 210 pages.

WEGENER, MICHAEL et. Franz Furst, 2004, Land-use transport interaction: state of the art. Available at SSRN 1434678.

WIEL M, 1999, La transition urbaine ou le passage de la ville pédestre à la ville motorisée, éd. Pierre Margada, Liège, coll. Recherches et Architecture, 149 pages.

WIEL M, 2002, Ville et automobile, éd. Descartes \& Cie, coll. Les urbanités, 140 pages.

WIEL M, 2006, Ville et mobilité, un couple infernal ? , éd. de l'Aube, coll. Intervention, 90 pages. 